\title{
Use of active metabolites of vitamin D orally for the treatment of psoriasis
}

\begin{abstract}
1.Academic Course of Medicine, University of West Paulista (UNOESTE), Presidente Prudente/São Paulo, Brasil. 2.Full Professor of the Discipline of Dermatology, University of West Paulista (UNOESTE), Presidente Prudente/São Paulo, Brasil and Chief of Dermatology Service of the Regional Hospital of Presidente Prudente, Presidente Prudente/São Paulo, Brasil.
\end{abstract}

http://dx.doi.org/10.1590/1806-9282.64.07.643

\begin{abstract}
SUMMARY
Objective: The objective of this study was to analyse the existing bibliographic production on clinical trials related to the use of vitamin $D$ for oral treatment of psoriasis. Method: A literature review of clinical trials related to the use of vitamin D for oral treatment of psoriasis, published in the LILACS, Scielo, Medline, PubMed and Cochrane Library from 1986 to 2013. The search included the following terms: "Psoriasis and oral Vitamin D"; "psoríase e vitamina D oral". Results: After analysing the titles and summaries, 10 articles met the eligibility criteria. Discussion: According to the literature, most tests were made in moderate psoriasis with doses ranging from 0.25 to $2 \mu \mathrm{g}$, demonstrating improvement with this treatment modality. Some studies suggest the use of high doses, but the biggest concern is hypercalciuria as a side effect.Conclusion: The use of active metabolites of vitamin D orally for the treatment of psoriasis showed efficacy and safety.

KEYWORDS: Administration, oral. Review literature as topic. Psoriasis. Vitamin D.
\end{abstract}

\section{INTRODUCTION}

Psoriasis is a chronic inflammatory skin disease that affects about $2 \%$ of the world's population and 3 million people in Brazil. It is characterized by erythematous and scaly papules or plaques, usually located in the elbows, knees, feet, hands, sacral region, and scalp or even throughout the body, with periods of exacerbations, remissions and recurrences. According to the location or characteristics of the lesions, it can be classified as plaque, guttate, inverted, pustular (generalized and localized), palmoplantar, scalp, nail, erythrodermic and arthropathic psoriasis (Figures 1, 2 and 3). Although psoriasis does not affect survival, it has a negative impact on the patient's physical and psychosocial well-being, as the appearance of the lesions is a cause for stigma'.
The pathophysiology of psoriasis defines it as an immune-mediated systemic disease involving helper T lymphocytes type 1 (Th1). Cytokines of the Th1 pathway - interferon gamma, interleukins 2 and 12 and TNF-alpha - predominate in the psoriatic plaques, as well as interleukin-17, which induces the expression of chemoattractant in the lesion. Therefore, an unknown stimulus activates the dendritic cells that present antigens of the skin, which will lead to the activation of the helper T cells, and, finally, the release of a cascade of inflammatory cytokines. This cascade results in the recruitment and activation of other cells, such as neutrophils and endothelial cells, chemokines and growth factors that will induce keratinocyte proliferation. A chronic condition, there-

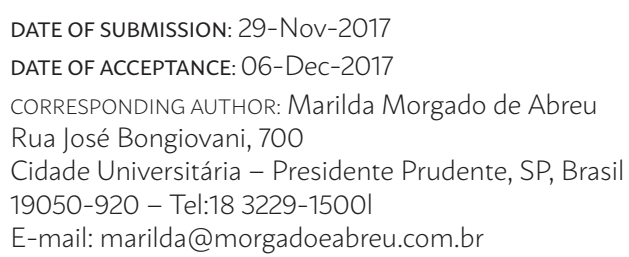


fore, guarantees and leads to the formation of skin lesions in psoriasis ${ }^{2}$.

In addition, psoriasis is nowadays associated with vitamin D deficiency. A study by Gisondi et al. ${ }^{3}$, which analysed the vitamin D status in patients with chronic plaque of psoriasis, demonstrated that vitamin D deficiency is common in these patients, regardless of age, gender, body mass index, Psoriasis

\section{FIGURES 1,2 and 3}
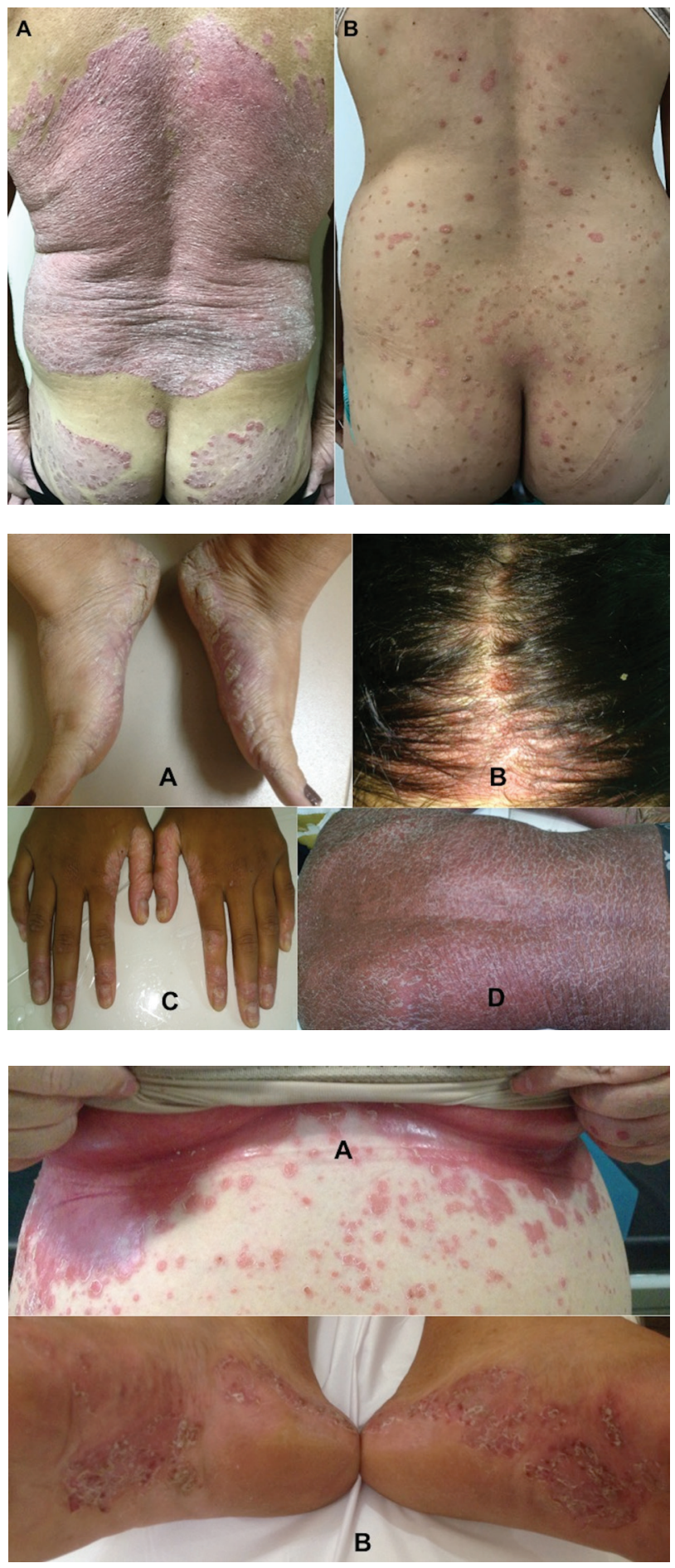

Area Severity Index (Pasi), parathyroid levels (PTH) and blood collection time.

Vitamin D - or cholecalciferol - is a steroid hormone that has endogenous formation in cutaneous tissues after exposure to ultraviolet $\mathrm{B}$ radiation. Cholecalciferol circulates in protein-bound blood and, when it reaches the liver, undergoes hydroxylation, forming 25-hydroxyvitamin $\mathrm{D}$ or $25(\mathrm{OH}) \mathrm{D}_{3}$, which in spite of being biologically inert, represents the circulating form in greater amounts of vitamin D. Blood levels of 25(OH)D3 correspond in proportion to the amount of vitamin D that is ingested or produced on the skin. The final stage of production of the hormone is its hydroxylation in the kidney, where the biologically active form of vitamin $\mathrm{D}$, calcitriol or $1,25(\mathrm{OH}) \mathrm{D}_{3}$ will be synthesized. The main function of vitamin $\mathrm{D}$ in the body is to participate in calcium homeostasis, stimulating the active transport of this ion in enterocytes ${ }^{4}$. In addition, many cell types involved in immune responses not only express vitamin D receptors, but also have all the enzymatic machinery for the local synthesis of 1,25(OH)2 D3; these sites of synthesis in cells related to immunity are of great importance for the regulation and control of various immune responses ${ }^{5}$. Thus, the existence of extra-renal hydroxylation of vitamin $\mathrm{D}$, with autocrine or paracrine action, has the function of inhibiting cell proliferation, promoting cell differentiation and regulating immunological mechanisms ${ }^{4}$, such as the control of the inappropriate activation of interleukin-17, which participates in the pathogenesis of multiple inflammatory and autoimmune diseases ${ }^{6}$.

Topical vitamin D derivatives have immunomodulatory effects on monocytes, macrophages, $\mathrm{T}$ lymphocytes and dendritic cells. Thus, topical vitamin D products have been widely used in monotherapy or in combination with steroids ${ }^{3}$. The latter alternative is considered first-line therapy for the majority of patients with mild to moderate psoriasis, demonstrating efficacy and safety in treatment of patients with plaque psoriasis ${ }^{7}$.

However, evidence that psoriasis is a systemic disease, involving many comorbidities, suggests the importance of analysing the treatment of this disease with oral vitamin $\mathrm{D}$, given the few studies investigating this modality in patients with psoriasis ${ }^{2}$. Doses of oral vitamin D can be expressed in microgram or International Unit (IU), with 1 microgram corresponding to $40 \mathrm{IU}^{8}$. In addition, when the literature is observed, the forms of vitamin D used for oral treat- 
ment may be: $1,25(\mathrm{OH}) \mathrm{D}_{3}$, which is the biologically active form of this hormone or $1 \alpha(\mathrm{OH}) \mathrm{D}_{3}$, which is a precursor $1.25(\mathrm{OH}) \mathrm{D}_{3}{ }^{9-16}$.

\section{OBJECTIVE}

This study aims at analysing the literature on the clinical trials related to the use of vitamin D for oral treatment of psoriasis. It will be analysed especially the type of psoriasis in which the treatments were applied, results, side effects and doses used in this therapeutic alternative.

\section{METHODS}

This is a bibliographic review research using the online databases Lilacs, SciELO, Medline, PubMed and Cochrane Library, consulted from the portal of free and restricted databases of the virtual library of the Universidade do Oeste Paulista.

Thus, a search was initially made on the production of knowledge regarding the oral use of vitamin D for the treatment of psoriasis.

In the search, the titles and abstracts of the articles were considered for the broader choice of probable papers of interest, being selected the articles that provided complete texts. The descriptors used were "Psoriasis and oral Vitamin D"; "psoríase e vitamina D oral".

At the end of the research, ten articles were selected for the study, covering the period between 1986 and 2013.

\section{RESULTS}

The research strategy was to analyse the titles and abstracts of the articles. According to the topic of interest, ten articles, published in the period between 1986 and 2013, were used to carry out the literature review.

\section{DISCUSSION}

The therapeutic use of vitamin $D$ in psoriasis dates back to the 1930s when the compound was used as an oral agent to treat osteoporosis in a patient with psoriasis where subsequently the improvement of psoriatic skin lesions was observed ${ }^{9,10}$.

In 1986, Morimoto et al. ${ }^{11}$, in an open-label clinical trial, and Takamoto et al. ${ }^{12}$, in a pilot study, selected patients with psoriasis vulgaris, resistant to topical corticosteroid therapy, and administered $1 \mathrm{\mu g}$ /day of $1 \alpha(\mathrm{OH}) \mathrm{D} 3$ for six months. The authors demonstrated that the biologically active metabolites of vitamin D3 are effective in therapy of the disease and do not cause apparent side effects.

Smith et al. ${ }^{13}$ studied 14 patients with psoriasis from moderate to extensive lesions. They administered 1,25-(OH)2D3, at the initial dose of $0.25 \mu \mathrm{g}$, once or twice daily. Patients should limit daily calcium intake to less than $800 \mathrm{mg}$. If they had normocalciuria at the follow-up, the dose was increased to a maximum of $2 \mu \mathrm{g} /$ day; if hypercalciuria occurred, therapy was discontinued. Hypercalciuria was observed when fractionated doses of vitamin D exceeded $0.75 \mu \mathrm{g} /$ day. To avoid this effect, the dosage was changed to only one dose of 0.25 to $0.5 \mu \mathrm{g}$ before bedtime: the authors believe that the influence of 1,25-(OH)2D3 on the absorption of calcium by the intestine is lower at night; therefore, higher doses administered before bedtime possibly cause a lower risk of hypercalciuria. In this study, 13 of the 14 patients improved with two months of treatment and continued to improve up to 6-8 months after the initial improvement was observed.

El-Azhary et al. ${ }^{14}$, in a pilot study, treated eight patients with psoriasis vulgaris, presenting more than $25 \%$ of body involvement at an initial dose of 1,25-(OH)2D3 of $0.5 \mu \mathrm{g}$ before bedtime. This dose was beneficial for one patient, who had psoriatic plaques completely resolved within two months and no side effects. Patients receiving dosages greater than $1 \mu \mathrm{g} /$ day showed an increase in calcium excretion in the urine for 24 hours. Considering this, they do not recommend the use of doses above $1 \mu \mathrm{g} /$ day. The research also shows that serum vitamin D levels do not correlate with disease activity.

Perez et al..$^{15}$ conducted a clinical trial to test the safety and efficacy of oral calcitriol to treat psoriasis in 85 patients with at least $15 \%$ of the body affected by the disease. The initial dose was $0.5 \mu \mathrm{g} / \mathrm{day}$ of vitamin $\mathrm{D}$ before bedtime and was subsequently increased by $0.5 \mu \mathrm{g} /$ day every two weeks, with laboratory control of serum calcium and urine for 24 hours; while these tests remained within normal range, the dose of vitamin D would be increased. The treatment lasted between 6 and 36 months; the maximum tolerated dose was $4 \mu \mathrm{g} /$ day and the average dose ranged from $2.1+/-0.8 \mu \mathrm{g} / \mathrm{night}$ for treatments lasting 24 months and $2.4+/-0.6 \mu \mathrm{g} /$ night for treatments of 36 
months. The results were $88 \%$ of patients improved their clinical condition, $26.5 \%$ had complete improvement, $36.2 \%$ had moderate improvement and $25.3 \%$, slight improvement.

Huckins et al. ${ }^{16}$ performed an open-label trial using $1,25-(\mathrm{OH}) 2 \mathrm{D} 3$ for the treatment of psoriatic arthritis in ten patients at an oral dose of $2 \mu \mathrm{g} /$ day for six months. More than 50\% achieved substantial improvement and $25 \%$ improved moderately. The conclusion of the study was that high doses of vitamin D could be used as a therapeutic agent of psoriatic arthritis.

Werner de Castro et al. (2012) ${ }^{17}$ mention the resolution of a psoriasis case, induced by the use of adalimumab, in a woman with rheumatoid arthritis, after using high doses of vitamin D to treat the deficient rates of this vitamin.

A pilot study by Finamor et al. (2013), ${ }^{6}$ evaluated the effect of prolonged oral administration of high daily doses of vitamin D in the clinical course of 16 patients with vitiligo and 9 patients with psoriasis, using 35,000 IU per day for six months. This study suggested that high daily doses of vitamin D might be particularly critical for controlling the activity of autoimmune disorders. Cumulative data from the past 30 years, reviewed by the authors, establish a regulatory effect of vitamin $\mathrm{D}$ on the innate and adaptive immune response, with circulating levels of $25(\mathrm{OH}) \mathrm{D} 3$ - the main circulating form of vitamin D - inversely related to autoimmune disease activity. They state that doses of up to 40,000 IU per day of vitamin D3 are probably safe for healthy individuals and that in patients with autoimmune disorders, polymorphisms that affect vitamin D metabolism enzymes may increase their tolerability. They also point out that hypervitaminosis D are associated with the positive regulation of intestinal vitamin $\mathrm{D}$ receptors and increased dietary calcium absorption; a calcium-deficient diet protects against vitamin D toxicity not only by reducing calcium available for intestinal absorption but also by facilitating vitamin $D$ inactivation at sites related to calcium metabolism. In the pilot study, all patients had clinical improvement of the cutaneous condition without side effects: serum calcium concentrations (total and ionized) were measured and did not differ significantly from baseline values after six months of high treatment doses with vitamin D3. The urinary excretion of calcium increased considerably, but remained within the normal range. The dose chosen by the authors of $35,000 \mathrm{IU}$ was selected arbitrarily, as well as other interventions that have already been applied to treat autoimmune disorders using high doses of vitamin D3, however it is suggested that PTH may be the best biological indicator for the individual establishment of the optimal dose of vitamin D3 for the treatment of autoimmune disorders. The magnitude of reduction in PTH serum concentration from baseline to the level reached after the treatment period may provide a reasonable estimate of how much the initial daily dose of vitamin D3 should be increased to reduce serum PTH levels below reference range.

TABLE 1: STUDIES EVALUATING THE EFFICACY OF USING THE ACTIVE METABOLITES OF ORAL VITAMIN D FOR THE TREATMENT OF PSORIASIS.

\begin{tabular}{|c|c|c|c|c|c|}
\hline $\begin{array}{l}\text { Author/ } \\
\text { Year }\end{array}$ & Type of Study & $\begin{array}{l}\text { Number of } \\
\text { patients }\end{array}$ & $\begin{array}{l}\text { Clinical presentation } \\
\text { of psoriasis }\end{array}$ & Initial Dose & Study Contribution \\
\hline $\begin{array}{l}\text { Morimoto et al. } \\
\text { (1986) }\end{array}$ & $\begin{array}{l}\text { Open-label } \\
\text { clinical trial }\end{array}$ & 17 & $\begin{array}{l}\text { mild to moderately } \\
\text { refractory psoriasis }\end{array}$ & $1 \mu \mathrm{g} /$ day & $\begin{array}{l}\text { It demonstrated the efficacy of using } \\
\text { active metabolites of vitamin D3, with } \\
\text { no apparent side effects. }\end{array}$ \\
\hline $\begin{array}{l}\text { Takamoto et al. } \\
\text { (1986) }\end{array}$ & Pilot Study & 7 & $\begin{array}{l}\text { psoriasis vulgaris for } \\
\text { more than } 6 \text { months } \\
\text { and refractory }\end{array}$ & $1 \mu \mathrm{g} /$ day & $\begin{array}{l}\text { It demonstrated the efficacy of using } \\
\text { active metabolites of vitamin D3, with } \\
\text { no apparent side effects. }\end{array}$ \\
\hline $\begin{array}{l}\text { Smith et al. } \\
\text { (1988) }\end{array}$ & $\begin{array}{l}\text { Double-blind } \\
\text { Clinical Trial }\end{array}$ & 14 & $\begin{array}{l}\text { moderate to severe } \\
\text { psoriasis vulgaris }\end{array}$ & $\begin{array}{l}0.25 \text { to } 0.5 \\
\mu g / \text { day }\end{array}$ & $\begin{array}{l}\text { Dosage should be } 1 \text { dose before bed- } \\
\text { time to avoid hypercalciuria. }\end{array}$ \\
\hline $\begin{array}{l}\text { Huckins et al. } \\
\text { (1990) }\end{array}$ & $\begin{array}{l}\text { Open-label } \\
\text { clinical trial }\end{array}$ & 10 & psoriatic arthritis & $2 \mu \mathrm{g} /$ day & $\begin{array}{l}\text { High doses of vitamin D may be useful } \\
\text { for psoriatic arthritis therapy. }\end{array}$ \\
\hline $\begin{array}{l}\text { El-Alzhari et al. } \\
\text { (1993) }\end{array}$ & Pilot study & 8 & $\begin{array}{l}\text { moderate to severe } \\
\text { psoriasis vulgaris }\end{array}$ & $0.5 \mu \mathrm{g} /$ day & $\begin{array}{l}\text { It does not recommend doses higher } \\
\text { than } 1 \mu \mathrm{g} / \text { day. }\end{array}$ \\
\hline $\begin{array}{l}\text { Perez et al. } \\
\text { (1996) }\end{array}$ & $\begin{array}{l}\text { Open-label } \\
\text { clinical trial }\end{array}$ & 85 & $\begin{array}{l}\text { moderate to severe } \\
\text { psoriasis vulgaris }\end{array}$ & $0.5 \mu g /$ day & Maximum tolerated dose of 4 mg/day. \\
\hline $\begin{array}{l}\text { Finamor et al. } \\
\text { (2013) }\end{array}$ & $\begin{array}{l}\text { Open-label } \\
\text { clinical trial }\end{array}$ & 9 & $\begin{array}{l}\text { moderate to severe } \\
\text { psoriasis vulgaris }\end{array}$ & $\begin{array}{l}35.000 \mathrm{UI} / \\
\text { day }\end{array}$ & $\begin{array}{l}\text { High doses of vitamin D may be safe } \\
\text { and effective for treating psoriasis. }\end{array}$ \\
\hline
\end{tabular}


According to Gisondi et al. (2011) $)^{3}$, the toxicity of vitamin D supplementation is very rare to occur and consists mainly of acute hypercalcemia, which usually results from doses exceeding 10,000 IU per day.

On the other hand, Trémezaygues and Reichrath $(2011)^{5}$ affirm that only supraphysiological doses lead to a clinical improvement of psoriasis, therefore, the use of vitamin D analogues in dermatology was considered, decades ago, limited due to the occurrence of serious effects related to calcium metabolism.

Furthermore, Smith et al. $(1988)^{13}$, in the literature review they did to compare the results obtained in their clinical trial, report that in the 1930s and 1940s there were studies in which extremely high doses of vitamin D (around 100,000 IU) were administered to treat a variety of skin disorders such as scleroderma, eczema, acne and psoriasis. Although some responses were favourable, the doses required were very toxic, and since vitamin D is biologically inert, successive hydroxylation is required in the liver and later in the kidneys, in order to form 1,25-(OH)2D3 and thus have biological activity. They conclude that increased intake of vitamin $\mathrm{D}$ has few beneficial effects.

\section{PRACTICAL ASPECTS OF THIS REVIEW}

According to the literature, oral vitamin D testing was primarily performed on moderate to severe vulgar psoriasis. Most studies have shown that the active metabolites of vitamin D3 - 1,25-(OH)2D3 or $1 \alpha(\mathrm{OH}) \mathrm{D}_{3}$ (synthetic analogue of $\left.1,25-(\mathrm{OH}) 2 \mathrm{D} 3\right)$ - pro- vide favourable results in the evolution of psoriasis and cause few side effects, and may be a therapeutic alternative for the treatment of this disease. The most worrying adverse effect that can occur is acute hypercalciuria, which can be avoided by restricting daily calcium intake (less than $800 \mathrm{mg}$ per day), by administering vitamin $\mathrm{D}$ at night - before bedtime - and by properly monitoring, throughout the treatment, urinary calcium levels; if the patient has hypercalciuria, the use of vitamin $D$ should be stopped. The doses that can be used vary from $0.25 \mu \mathrm{g}$ to 2 ug per day, but recently, a higher dose (35,000 IU) has shown therapeutic safety and efficacy, and PTH is the best biological indicator for the establishment of the vitamin D3 dose.

\section{CONCLUSION}

The review of the literature revealed that there are still few studies that have tested the use of oral vitamin D active metabolites for the treatment of psoriasis, in addition to the fact that the sample studied in all of them is small and the follow-up time is very limited. However, existing data suggest that such a therapeutic alternative is safe and effective. Therefore, more studies are needed, in the long term and in larger cases, to try to establish an adequate protocol of treatment and thus to reach a consensus as to the doses and time that should be employed, since this alternative is low cost and apparently safe, even at high doses, unlike most systemic drugs currently used in psoriasis, the adverse effects of which are significant and many of them are costly.

\section{RESUMO}

OBJETIVO: O objetivo deste estudo foi analisar a produção bibliográfica existente sobre os ensaios clínicos relacionados ao uso da vitamina D para tratamento por via oral da psoríase. MÉTODos: Revisão de literatura de ensaios clínicos relacionados ao uso de vitamina D para tratamento por via oral da psoríase publicados no Lilacs, SciELO, MedLine, PubMed e Biblioteca Cochrane no período de 1986 a 2013. A pesquisa incluiu os seguintes termos: "Psoriasis and oral Vitamin D"; "psoríase e vitamina D oral". RESULTADOS: Depois de analisar os títulos e resumos, dez artigos preencheram os critérios de elegibilidade. DISCussão: Segundo a literatura, a maioria dos ensaios foi realizada na psoríase moderada, com dose que varia de 0,25 a $2 \mu \mathrm{g}$, demonstrando melhora com esta modalidade terapêutica. Alguns estudos sugerem o uso de doses elevadas, porém a maior preocupação é a hipercalciúria como efeito colateral. CONCLUSÃo: $O$ uso de metabólitos ativos de vitamina D por via oral para o tratamento da psoríase demonstrou eficácia e segurança com relação aos efeitos colaterais.

PALAVRAS-CHAVE: Administração oral. Literatura de revisão como assunto. Psoríase. Vitamina D. 


\section{REFERENCES}

1. Rodrigues AP, Teixeira RM. Desvendando a psoríase. Rev Bras Ana Clin. 2009;41(4):303-9.

2. Fu LW, Vender R. Systemic role for vitamin D in the treatment of psoriasis and metabolic syndrome. Dermatol Res Pract. 2011;2011:276079.

3. Gisondi P, Rossini M, Di Cesare A, Idolazzi L, Farina S, Beltrami G, et al. Vitamin D status in patients with chronic plaque psoriasis. Br J Dermatol. 2012;166(3):505-10.

4. Marques CDL, Dantas AT, Fragoso TS, Duarte ALBP. A importância dos níveis de vitamina $D$ nas doenças autoimunes. Rev Bras Reumatol. 2010;50(1):67-80.

5. Trémezaygues L, Reichrath |. Vitamin D analogs in the treatment of psoriasis: Where are we standing and where will we be going? Dermatoendocrinol. 2011;3(3):180-6.

6. Finamor DC, Sinigaglia-Coimbra R, Neves LC, Gutierrez M, Silva JJ, Torres LD, et al. A pilot study assessing the effect of prolonged administration of high daily doses of vitamin $D$ on the clinical course of vitiligo and psoriasis. Dermatoendocrinol. 2013;5(1):222-34.

7. Patel M, Day A, Warren RB, Menter A. Emerging therapies for the treatment of psoriasis. Dermatol Ther (Heidelb). 2012;2(1):16.

8. Althoff MEWS, Ramos DMB, Silva DMW, Santos Neto PE. A importância da vitamina $D$ na prevenção de fraturas em adultos acima de 45 anos. RBNE. 2009; 3(13): 50-62.

9. Nagpal S, Lu |, Boehm MF. Vitamin D analogs: mechanism of action and therapeutic applications. Curr Med Chem. 2001;8(13):1661-79.
10. Kim GK. The rationale behind topical vitamin d analogs in the treatment of psoriasis: where does topical calcitriol fit in? | Clin Aesthet Dermatol. 2010;3(8):46-53.

11. Morimoto S, Yoshikawa K, Kozuka T, Kitano Y, Imanaka S, Fukuo K, et al. Treatment of psoriasis vulgaris by oral administration of 1 alpha-hydroxyvitamin D3: open-design study. Calcif Tissue Int. 1986;39(3):209-12.

12. Takamoto S, Onishi T, Morimoto S, Imanaka S, Yukawa S, Kozuka T, et al. Effect of 1 alpha-hydroxycholecalciferol on psoriasis vulgaris: a pilot study. Calcif Tissue Int. 1986;39(6):360-4.

13. Smith EL, Pincus SH, Donovan L, Holick MF. A novel approach for the evaluation and treatment of psoriasis. Oral or topical use of 1,25-dihydroxyvitamin D3 can be a safe and effective therapy for psoriasis. I Am Acad Dermatol. 1988;19(3):516-28.

14. el-Azhary RA, Peters MS, Pittelkow MR, Kao PC, Muller SA. Efficacy of vitamin D3 derivatives in the treatment of psoriasis vulgaris: a preliminary report. Mayo Clin Proc. 1993;68(9):835-41.

15. Perez A, Raab R, Chen TC, Turner A, Holick MF. Safety and efficacy of oral calcitriol (1,25-dihydroxyvitamin D3) for the treatment of psoriasis. Br J Dermatol. 1996;134(6):1070-8.

16. Huckins D, Felson DT, Holick M. Treatment of psoriatic arthritis with oral 1,25-dihydroxyvitamin D3: a pilot study. Arthritis Rheum. 1990;33(11):1723-7.

17. Werner de Castro GR, Neves FS, Pereira IA, Fialho SC, Ribeiro G, Zimmermann AF. Resolution of adalimumab-induced psoriasis after vitamin D deficiency treatment. Rheumatol Int. 2012;32(5):1313-6. 